\title{
ボルドー合劑撒布による藥害と 降雨との關係に就て(豫報)
}

杉川直儀

（東京帝國大學䢉部）

\section{I 緒 言}

ボルドー合劑は最も普通に使用されてるる殺菌用撒布藥劑であつて我が國で 女明治年間から使用せられ果樹蔬荣其他農作物一般の病害豫防の上飞非常な貢 獻をして來を事は誰しも認める所である。然し乍らボルドー合劑は撒布された 作物自體ても時としては害作用を與へる事が知られ殊に果樹の中の核果類や蔬 荣の中の白荣類等には薬害が特に著しいので撒布が禁ぜられて居り, 其他の果 樹蔬荣の中にも天候の具合や其他で時として可なり著しい被害を受ける事があ る。

ボルドー合齊撒布による藥害の程度は藥劑の組成によつて可なりの差異があ る。ボルドー合劑は硫酸銅液と石灰水を混合して作るが，兩者の比及び濃度を 適當なるのを撰ぶ事によつて藥害を或程度避け得るのであつて此の點に就ては 從來の長い經驗によつて石灰の多いものがよいとか少ないものがよいとか，ぼ の程度の濃度のものがよいとか冬作物化對する大體の處方がきめられてるるの であるが，それも人によつて區々であつて何れをとるべきかを迷ふ事があり， 而も何故に其の樣な處方がよいのかといふ理由に就ては明らか李根據を得られ ない場合が屡々である。此等を實驗的に决定してゆく事は實用上極めて重要な 事ではあるが都合の惡い事にボルドー合劑撒布による藥害は常に同じ樣には現 はれてくれないのである。從つて我々は藥害の多少に就ては常に藥劑の組成と 共に重要な要素が別にある事を考虑せ奺ばならない。

ボルドー合劑撒布による藥害は天候によつて其現れ方に非常な相違が認めら れる。同じ種類の作物に同じ處方てよつて調合したボルドー合劑を撒布しても 
時には藥害が現はれ時には藥害が現はれない。核果類の樣に藥劑に弱いもので も天候によつては容易に藥害の現はれない事さへある。此の事は云ふ汽もなく 外的條件をる氣象要素の中にボルドー合劑撒布による藥害に對する决定的な因 子が存在する事を示すものである。しかも藥害は此の要素に支配される事がき はめて著しいのであるから，此の要素を豫め明らかにして羁かなければ撒布實 施にも處方の汽定にもいささか不安定である樣に思はれる。又此要素を明らか にする事は如何にして藥害が起るかとんふ機構を知る上にも必要であり, 進ん では我くの理想とする藥害を惹起しない新しい藥劑を作る上にも何等かの參考 てなると考へるのである。

ボルドー合劑撒布による藥害は雨の多い濕潤な天候の下に於て最も著しい事 は廣く知られてるる所である。New York 州農事試驗場の HEDRICK 氏年每て 同州の當業者並に冬州及諸外國の技術者に對してボルドー合劑撒布による些果 の藥害がどの樣な折に最も著しいかといふ問を發した所，大多數の人々から撒 布後に雨の降る樣な場合に被害が最も著しいといふ司答が得られた。HEDRICK 氏自身も苹果園にボルドー合劑を撒布して降雨の後に藥害が現はれる事を觀察 しでるる。此の事は米國に限らずボルドー合劑撒布に經驗のある人の大多數は 認めてるる事であらうが此の雨の多い濕潤な氣候と云はれてみるものの中でそ れでは何れの氣象要素一濕度，溫度，日射，降水等一が最も大きい役割をなす かと云ふ事に就てはつきり證明した人は意外に少なく, 筆者の知つてるる範圍 では 1902 年に發表された BAIN 氏の論文があるのみの樣である。彼はボルド 一合劑を撒布した桃樹に天幕で蔽ひをして置くと雨があつても藥害が現はれな い所から，藥害は葉に雨露がかからねば起らないと述べてるる。筆者もボルド 一合劑撒布による藥害に就て觀察中ボルドー合劑を撒布しても其後降雨がなけ れば藥害は現はれないが，降雨があると其の後になつて藥害があらはれる事か ら 1938-39 の兩年に降雨と藥害との關係に就て二三實驗を試みをが其結果を 茲に報告しようと思る×。

實驗の逐行にあたつて懇切なる御指導を賜はつた淺見呚授に 深謝の意を表するととも に，自然科學研究獎勵金を補助された文部省に件せて謝意を表する次第である。 


\section{II ボルドー合劑の處方，調製及び撒布}

ボルドー合劑の調製には化學用最純級の硫酸銅と水酸化石灰とを使用した。 硫酸銅と水酸化石灰々をとれぞれ牛量の水に溶解して置き（水酸化石灰は全部 は溶けきれない)，撒布前に硫酸銅液を石灰水に注加攪拌して調製した。水は初 年は事溜水を使用したが，其の後は水道水を使用してるる。少展着劑は一切加 用しなかつた。撒布にあたつては小型噴霧器で葉先から滴の落ちる程度に充分 撒布した。

硫酸銅と石灰の配合量は最も多く用ひたのは次の 3 種である(第 1 表)。 第 1 表ボルドー合劑の處方

\begin{tabular}{|c|c|c|c|c|c|c|c|}
\hline \multirow{2}{*}{ 種 類 } & \multirow{2}{*}{ 從來の呼稱 } & \multicolumn{3}{|c|}{$1 \mathrm{~L}$ の水に對し } & \multirow{2}{*}{ 色 } & \multirow{2}{*}{ 反 } & \multirow{2}{*}{ 應 } \\
\hline & & 硫酸銅 & $\begin{array}{l}\text { 水酸化 } \\
\text { 石 灰 }\end{array}$ & 生石灰として & & & \\
\hline $6-1.5$ & 4 斗式少石灰ボルドー & $6 g r$ & $2 g r$ & $\stackrel{\mathrm{gr}}{1.513 \fallingdotseq 1.5}$ & 帶綠靑色 & & 性 \\
\hline $6-6$ & 4 斗式等量ボルドー & 6 & 8 & $6.052 \fallingdotseq 6$ & 碧青色 & アルカ & リ性 \\
\hline $6-18$ & 4 斗式過石灰ボルドー & 6 & 24 & $18.156 \fallingdotseq 18$ & 青白色 & アルカ & リ性 \\
\hline
\end{tabular}

本報では便宜上ボルドー合劑の處方を從來の呼稱で表はす代りに 6 - $1.5,6$ 6，6-18 等の記號で表はしてわるが例へば 6-1.5 ボルドーとは 4 斗式少石灰 ボルドーであり，最初の 6 は水 $1 \mathrm{~L}$ に配合する硫酸銅つ瓦數を示し，次の 1.5 は同じく水 $1 \mathrm{~L}$ 亿對し生石灰 $1.5 \mathrm{gr}$ を配合する事を示す多ので，又 $6-1.5$ と 云へば石灰の量が硫酸銅の量の $1 / 4$ である極端な少石灰ボルドーである事も同時 に此記號から讀み取るととが出來るのである。同樣に 6 -6 ボルドーは 4 斗式 等量ボルドーを，6-18 は石灰が硫酸銅の 3 倍配合されてみる 4 斗式過石灰ボ ルドーを表はすものである。6-1.5 ボルドーは帶綠靑色の沈降の極めて僬い中 性ボルドーであるが，黃血覧による銅イオンの反應は認められ京い。6-6ボル ドーは碧靑色で液の反應はアルカリ性を示し，6-18 ボルドーは青白色で沈降 は早く反應は同じくアルカリ性を呈してるる。

\section{III 實 驗 結 果}

實驗 (1) ボルドー合劑撒布による藥害と降雨とがどの樣な關係にあるかを知 らうとして，作物に藥劑撒布後一半をガラス室內に搬入し他を室外に放置して 自然の雨露にあはしめ藥害の狀態を觀察した。降水量は少し距離が遠いけれだ 
も東大農學部から約 3 䉼離れてるる中央氣象臺で觀测された數字を引用した。

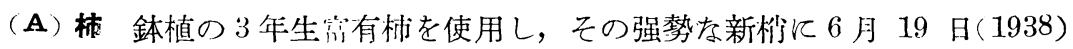
午後，6-1.5，6-3，6-6，6-18，6-30 の5 種類のボルドー合劑を撒布し一

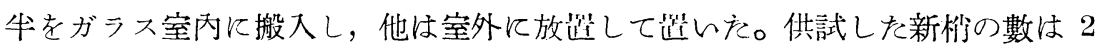
-3 本外で約 20 枚の葉をつけてみた。撒行後の天候を記すと第 2 表の如くで ある。藥憲は24 日迄認められなかつたが25日に室外區の 6-1.5ボルドーを 撒布したものに先づ現はれ，次で 28，29，30 日と大雨があつて室外區の全部 に藥害が現はれた。被害の程度は第 3 表に示す通りである。

第 2 装ボルドー合劑撒布後の天候

\begin{tabular}{|c|c|c|c|c|c|c|c|c|c|c|c|c|c|c|c|c|c|}
\hline 月 $\mathrm{日}$ & $\begin{array}{rr}4 & \\
6 & 19\end{array}$ & 20 & 21 & 22 & 23 & 24 & 25 & 26 & 27 & 28 & 29 & 30 & $\begin{array}{cc}19 & 1 \\
7 & 1\end{array}$ & 2 & 3 & 4 & 5 \\
\hline 天 候 & 基 & 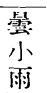 & 覺 & $\begin{array}{l}\text { 墨 } \\
\text { 後 } \\
\text { 晴 }\end{array}$ & 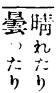 & $\begin{array}{c}\text { 晴毁 } \\
\text { 午後雨 }\end{array}$ & $\begin{array}{l}\text { 雨 } \\
\text { 後 } \\
\text { 昨青 }\end{array}$ & 晴 & 啨 & $\begin{array}{l}\text { 終 } \\
\text { 日 } \\
\text { 雨 }\end{array}$ & $\begin{array}{c}\text { 終 } \\
\text { 日 } \\
\text { 雨 }\end{array}$ & $\begin{array}{l}\text { 雨 } \\
\text { 後 } \\
\text { 礐 }\end{array}$ & 礐 & 雨 & 雨 & $\begin{array}{l}\text { 雨 } \\
\text { 惩 } \\
\text { 量 }\end{array}$ & 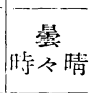 \\
\hline $\begin{array}{c}\text { 降水量* } \\
(\mathrm{mm})\end{array}$ & 0.1 & 3.1 & 0.0 & 0.0 & - & 18.2 & 30.0 & in & 0.2 & 109.2 & 278.3 & 39.7 & 1.6 & 88.3 & 63.5 & 45.8 & 0.4 \\
\hline
\end{tabular}

* 降水量は東大磨學部上り約 $3 \mathrm{~km}$ 離れて子る中央乘象臺の觀測による

第 3 表 柿, 室外區のボルドー合劑撒布による燕害の程度比較

\begin{tabular}{|c|c|c|c|c|c|c|}
\hline 調查月11 劑 & $6--1.5$ & $6--3$ & $6-6$ & $6--18$ & $6-30$ & 無撒布 \\
\hline 6月 25 月 & $+(1 / 4)$ & - & - & - & - & - \\
\hline 1 & $+++(2 / 3)$ & $++(1 / 3)$ & $+++(1 / 2)$ & ++ & + & - \\
\hline 5 & $+++(4 / 5)$ & $+++(x / 2)$ & $+++(2 / 3)$ & ++ & + & - \\
\hline
\end{tabular}

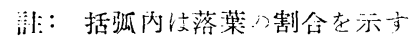

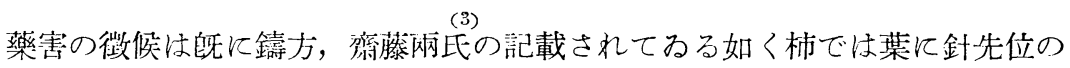

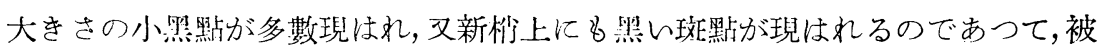
害の著しかつた 6-1.5 ボルドーを撒布した早のでは葉に於ける玟點の充分現 はれない前に落葉が起つた。斑點の著しく多い葉で後に徐々に黃變したものも ある。第 3 裴では藥害の程莅を葉の小黑㸃の多少によつて 3 階級に分ち，又别 に落葉の割合をも示してあるが, 此によると室外區では 6-1.5ボルドーが最も 被害著しく6月24日の小雨の翌日の25日に既に藥害が現はれ1/4洛葉してお る。數日の豪雨の後ボルドー合劑を掓们したものには處方の如何に拘ら亦尽部 藥害が現はれたが6-1.5 ボルドーを撒在したものでは7月 1 日に2/3，5日に4 
の落葉があつた。6-3，6-6 ボルドーを撒布した區も藥害は著しく落葉も最後 にそれぞれ $1 / 3$ ，1/2となつた。しかし 6-18 以上の石灰の多いボルドーを撒布し たものは落葉はなく被害の程度も石灰の多くなるに從つて輕微になつてるる。

此の間，ガラス室內に搬入されたるのは何れのボルドー合劑を撒布したもの も何等藥害の徵候が認められなかつた。

7 月 5 日に此等を再び室外に般出して監いた所降雨があつた後いづれも藥害 を生じたが，此の場合の被害は 6-1.5，6-3，6-6 はや〉多く 6-18，6-30 は極く輕微であつた。又冬區共落葉するものなく, 藥害の程度のボルドーの種 類による差もあまり明瞭でなかつた。

(B) 挑 柿之同樣に鉢植の 2 年生傳十郎 2 鉢の备々牛分に 6 月 22 日 6-6 ボ ルドーを撒布し，1 鉢をガラス室內に 1 鉢を室外に置いた。室外に置いたもの のボルドー合劑を撒布した枝では豪雨後紫褐色の斑點を葉及び新梢上飞生じ成 葉は全部落葉したが，ガラス室內に置いたものは何等異常を認めなかつた。此 を7月5日室外に出した所薬害を生じ，藥劑の办」つてみた葉は落葉し，撒布 當時嫩葉であつたものは落葉するに至らなかつたが穿孔病の如き害徵が現はれ た。

（C）菻豆, 小豆, 大豆 無儚荣豆 (サティスファクション)，小豆 (金時)，大 豆（鶴の子）を 9 月 2 日 7 寸鉢に播種し，冬鉢 3 本宛とし，9月 26 日何れ\& 第1複某の展開しかけを時に 6-1.5，6-6，6-18の3 種のボルドー合劑を撒 布した。各處理は 4 鉢宛とし 2 鉢はガラス室內に入れ，2 鉢は室外に置いた。 撒布後の天候壮第 4 表に示されてるる。

第 4 表 ボルドー合齋撒布後の天候

\begin{tabular}{|c|c|c|c|c|c|c|c|c|c|c|}
\hline 月 日 & $\begin{array}{ll}\text { म } & \text { म } \\
9 & 26\end{array}$ & 27 & 28 & 29 & 30 & $10 \stackrel{\text { म }}{1}$ & 2 & 3 & 4 & 5 \\
\hline 天 候 & 晴 & $\begin{array}{c}\text { 朝小雨 } \\
\text { 量 }\end{array}$ & 量 & 晴 & 量 & 晴 & 晴 & \begin{tabular}{|l|} 
雲後 \\
雨
\end{tabular} & 雨 & 晴 \\
\hline $\begin{array}{c}\text { 降水量 }{ }^{*} \\
(\mathrm{~mm})\end{array}$ & - & $0.0^{* *}$ & 0.0 & - & 0.0 & 0.0 & 0.3 & 4.1 & 75.8 & $(0.2)$ \\
\hline
\end{tabular}

*中央氣象薹の觀測による
9 月 27 日朝小 雨があり後降雨が なく 10 月に入り 3,4 の兩日江可 なりの降雨があつ た。藥害の調查は 9 月 30 日と 10 月 5 日の 2 包に行つてなるが室外區に於ける被害狀態は第 5 表の樣である。 
第 5 表 荣豆, 小豆及大豆，室外區のボルドー合劑撒布による藥害の程度比較

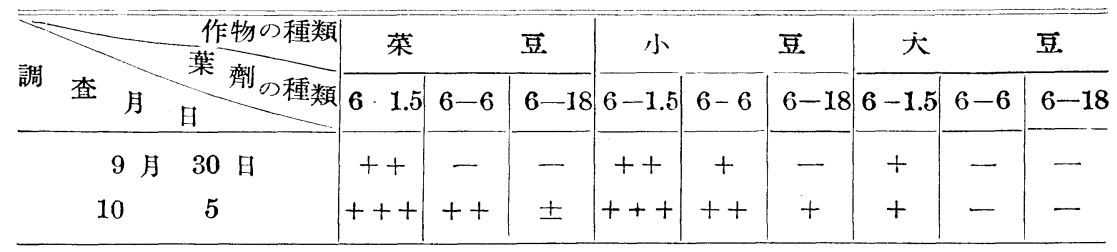

註：無撒布のものには異狀なし

荣豆の藥害の徵候は一對の單葉に褐色の小斑點を生じ被害の著しん時は黃變 落葉する。若い複葉には斑點が現はれなかつたが萎縮する傾向が認められた。 小豆の藥害の㣲候も荣豆と殆んど同じであつた。大豆では藥害が現はれ難いの は此の品種の葉の表面に蠟質物があり展着劑を加用しないボルドーが殆んに゙最 初から附着せないためであつて只，6-1.5 ボルドーを撒布したものでは新某が 縮れてみるのが見られたのみである。

上表を見ると石灰の少ない6-1.5 ボルドーを撒布したものが藥害最も著し く，又早く現はれてねる。

ガラス室內に入れて幒いたものは 10 月 5 日に至るも何等異狀を認めなかつ た。

(D) 梨 3 年生長十郎の鉢植を供試し 4 月 26 日（1939）午前に藥劑撒布 を行なつた。藥劑の種類は $6-1.5,6-6,6-18$ の 3 種のボルドー及び石灰單 用 $(0-10)$ の 4 種で冬藥劑を $250 \mathrm{ec} \mathrm{づつ} 2$ 鉢宛撒布しその中 1 鉢宛をガラス室 內に搬入し，他の 1 鉢宛を室外に置いた。藥劑撒布後の天候は次の通りである。 第 6 表 藥齊撒 布 後の天候

\begin{tabular}{|c|c|c|c|c|c|c|c|c|c|c|c|c|c|c|c|c|c|c|c|}
\hline 月 & $\mid$\begin{tabular}{c|} 
月日 \\
426
\end{tabular} & 27 & & 29 & 30 & $\begin{array}{|ll|}\text { 月 } & \text { 日 } \\
5 & 1\end{array}$ & 2 & 3 & 4 & 5 & 6 & 7 & 8 & 9 & 1011 & 12 & 13 & 14 & 15 \\
\hline 天 候 & $\begin{array}{l}\text { 裹 } \\
\text { 後 } \\
\text { 䨋 } \\
\end{array}$ & $\begin{array}{l}\text { 量後 } \\
\text { 雷雨 } \\
\end{array}$ & & $\begin{array}{l}\text { 决晴 } \\
\text { 洼薄墨 }\end{array}$ & 量 & $\begin{array}{l}\text { 是 } \\
\text { 時々 } \\
\text { 小雨 } \\
\end{array}$ & 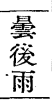 & $\begin{array}{l}\text { 快晴 } \\
\text { 一時 } \\
\text { 量 }\end{array}$ & 晴 & 㶧 & $\begin{array}{l}\text { 晴 } \\
\text { 後 } \\
\text { 䨋 } \\
\end{array}$ & 量 & $\begin{array}{l}\text { 量 } \\
\text { 後 } \\
\text { 霨 }\end{array}$ & 快 & 晴基情 & 雨 & \begin{tabular}{|c} 
雨 \\
時々 \\
量 \\
\end{tabular} & $\begin{array}{l}\text { 量 } \\
\text { 時々 } \\
\text { 小雨 } \\
\end{array}$ & 晴 \\
\hline $\begin{array}{l}\text { 降水量* } \\
(\mathrm{mm})\end{array}$ & 18.0 & 34.0 & & - & - & 0.1 & 7.0 & - & & $\ldots$ & 0.0 & 0.0 & 26.6 & & & 26.0 & 30.0 & 0.8 & - \\
\hline
\end{tabular}

藥劑を撒布した 26 日の午後より降雨あり，27日8雨で兩日に $52 \mathrm{~mm}$ の降 水量があつた。29 日に調查した所によると第 7 表の如く $6-1.5$ ボルドーを撒 布したものは被害著しく新葉成葉並に新杪に小黑點が多く現はれ若葉は萎縮し 
てみそ。6-6 ボルドーを撒布したものも同樣に藥害を生じたが 6-1.5 に比べ 第 7 表 梨, 各種藥劑撒布による藥害の比較

\begin{tabular}{|c|c|c|c|c|c|c|c|c|}
\hline 調査月日 & 澏 & 別 & 種類 & $6-1.5$ & $6-6$ & $6-18$ & $0-10$ & 無撒布 \\
\hline 4 月 29 口 & 室 & 外 & 煰 & +++ & ++ & + & $\ldots$ & - \\
\hline 5 月 15 凹 & 室 & 外 & 䛓 & +++ & ++ & + & - & -- \\
\hline 5 月 15 日 & 室 & $\begin{array}{c}5 \\
5\end{array}$ & $\begin{array}{l}10 \text { 是 } \\
\text { 出 }\end{array}$ & ++ & + & 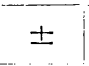 &..- & - \\
\hline
\end{tabular}
て其程度は輕く, 6 -18 ボルドー撒 布區に以若葉に黑 點を生じや〉萎縮 を見，成葉にも僅 に黑點が現はれた が大體藥害は極く輕微であつた。石灰單用及び無撒布のものには港狀を認めな レ。 5 月 $12 ， 13 ， 14$ の 3 日間に $56.8 \mathrm{~mm}$ の降雨があつた後 15 日に再び藥害 の程度を調查したが4月 29 日の場合と殆んど差は認められなかつた。

藥劑撒布後ガラス室內に置いたものは室外區に藥害が現はれても何等異狀な く5月 10 日迄藥害は現はれなかつた。 5 月 10 日に室外に出した所 $12 ， 13$, 14 の 3 日間の雨の後ボルドー合劑を撒布したものに藥害が認められた。その 程度は第て表下段に示す如く少石灰のものに著しく過石灰のものは少をく等量 式は其中間にあつた。しかし藥劑を撒布後最初から室外に通かれた外のと比べ ると何れも藥害の程度はや〉輕くなつてみる。

(E) 葡萄 2 年生のデラウ アアに月 9 日午後 $6-1.5,6-6,6-18$, 及び 0-6 の 4 種の藥劑を撒布した。室外區は圃場に定植されたものを用ひ，ガラ ス室內八搬入したものは鉢植を供試した。藥劑撒布後の天候は梨の場合を參照

第 8 裴 葡萄，藥劑撒布による藥害の 程度比較 (5月 15 日調查)

\begin{tabular}{|c|c|c|c|c|c|}
\hline 藥獭の種類 & $|6-1.5|$ & $6-6$ & $6-18$ & $0-6$ & 無撒行 \\
\hline 室 外 澡 & ++ & + & + &.$- \cdot$ & - \\
\hline
\end{tabular}
され度い。

5 月 $12,13,1403$ 日間飞 56.8 $\mathrm{mm}$ の降雨があつた後室外區では 藥害が現快れた。6--1.5ボルドー を撒布したものは葉に小黑斑を生じた。6-6 及6-18 ボルドーを撒布したも のにも值かではあるが小黑斑が現はれた。然し全體として葡萄のボルドー合劑 による被害は輕微の樣である。石灰のみ撒布したもの及び無撒布のものには異 狀を認めなかつた。

ガラス室內に型いたものは全部何等晎常を認めなかつたが，6月に入つて此 を室外に出した所 6-1.5 ボルドーを撒布したものの葉に小品斑を生じた。 


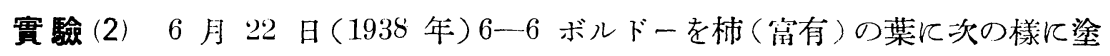
布した，(A) 丽面に塗布，(B) 表面のみに塗布，(C) 襄面のみに塗布，(D) 表面 のみに塗布して葉を裹返して茈いたもの，4種の處理を行なつた。其結果 (A)，(B)のみに藥害を見，(C)，(D) には垬常が認められなかつた。ボルドー合 劑を表面に整布したものでは藥害が現はれるが裹面に塗布したものには現はれ

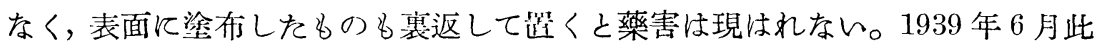
と同じ實驗を今一度柿で繰返した。以上の 4 區にボルドーを襄面のみに鋫布し て葉を裹返して品いた $(\mathrm{E})$ 區を加へて5區とした。其の結果藥害のあらはれ方 は1938年の場合と全く同梯で $(\mathrm{E})$ 區には值かに藥害が認められた。以上の結果 から柿の葉に藥害が起るには藥劑を塗布した面が上向になつてみる事が必要で あり，從つて降雨によつて葉面が濡れる事と藥害の出現との間に密接な關係が ある様に思はれる。

菑驗 (3) 實驗 (1)(2)の結果からボルドー合劑の撒布による藥害は藥劑を撒布 された葉面が降雨のために湍れる事によつて惹起される样であるから，次に人 爲的に葉を靁らして見て果して藥害が起るかどうかを檢した。

7 月 7 日（1938；鉢植の渻有柿の新梢の 1 枝每に 6-1.5, 6--6,6-18の 3 種類の違つそボルドーをそれぞれ撒布し，殘りの枝は無處理とした。7月8 日からガラス室內で 1 鉢宛人工降雨を降らせた。その方法は水道からゴムホー スを导きその先に如露の口金を附して放水し，降雨に擬したのである。そして 1 鉢づつ 10，24 及び 48 時間它處理した後ガラス室內で藥害の有無を檢した が何等害徽はあらはれなかつた。而も後に此を室外に出した所自然の降雨によ つて藥害を見たのである。

又て月て日に上と同樣に處理した㭪の葉の表面或は裹面に蒸溜水を含ませた 脫脂綿を 24 時間附着せしめて道いたが何等異常を示さなかつた。又柿に前と 同樣に 3 種のボルドー合劑を撒布したものにガラス室內で每日 1 時間多蒸溜水 乾かない程度に型霧器で蒸溜水を撒布し 1 週間繼續したが何等藥害を惹起す 事は出來なかつた。同年 11 月荣豆に上記の 3 種のボルドーを撒布し，後に記

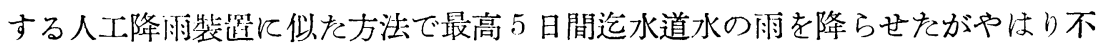
成功に終つた。蒸溜水を 24 時間降らせたっのも同樣に不成功であつた。1938 
年には其他數種の方法を試みたが何れも不成功に終つてしまつた。又ボルドー 合劑による藥害は降雨によらないのではないかといふ疑問を以て，藥齊を撒布 した植物を長く日陰に尷いたり，十二分に灌水したり，八リ鐘でお瓜つて多濕 にしたりしたけれを゙夕藥害は現はれなかつた。

以上二三の試みの不成功に終つたのは何故であるが今充分に說明出來ないの であるが考へられる事は處理方法が何れ名然の降雨と佾相當の差があると云
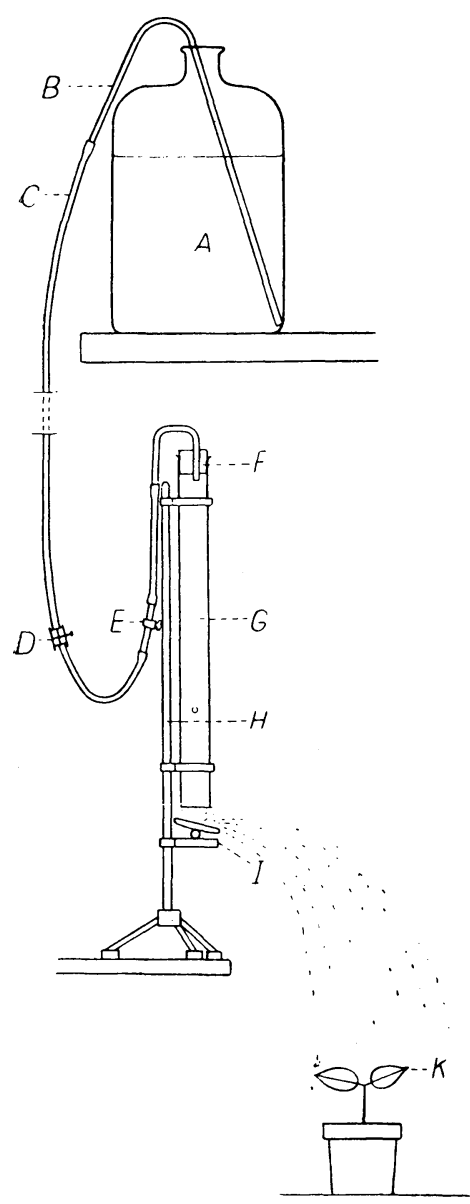

第 1 圖人 . . 降雨 裝 置 (模型圖)
A 野 水 瓶
B グラス管サイフォン
C ゴ ム管
D ピンチュック
$\mathrm{E}$ ガラス製コック
F ゴ 么 栓
G ガラス夙筒
$\mathrm{H}$ 支持 臺
I 磁製ルツボの蓋
$\mathrm{K}$ 錰植植物

Aの貯水瓶から年 管受びゴム管で尊かれた

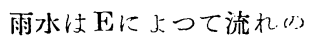
速度を調節されながら F のゴム栓についてねる 「コ」字型のガラス管の先 端から滴下し I U磁製の 且でハネ返つて四方に散 り下に置かれた錰植植物 Kを澏らす。Gのガラス 圆筒は風があつても水湖 が磁製の四の一定つ所侄 落ちる樣に保護する篇に 取付けられ，Dのピンチ コックは降雨を停める時 に使用する。A の貯水瓶 のつは一階にあり，他は 地階の雨のか」らない場 所に設置した。
ふ事である。それ で 1939 年には次 の點に注意して實 驗を繼續した。 （1）水道水や蒸溜 水の代りに雨水を 用ひる事。(2) 降 水狀態をもつと自 然の場合に類似さ せる事。(3) ボル ドー合劑撒布によ つて適確㓅且比較 的容易比藥害を生 する材料を用ひる 事。毁ち(1) 雨水 は磁製のポツトに たまつをものを集 めて使用した。(2) 降水狀態を自然の 洞に類似させる爲 に第 1 圖の樣な簡 易な人工降雨裝筈 を作つて用ひた。 
（3）材料としては富有柿及び苲麥が用ひられた。萻麥を用ひたのは生育が早 く，ボルドー合劑による藥害が容易に且明膫に現はれるからである。

5 月 26-27の兩日にわたつて前日 6-1.5 ボルドーを撒布して置いた柿及 蓄麥に人工雨を降らせた。雨水は 5 月 13 万至 15 日に降つたのを集めガラス 瓶中に密封斯藏したもの（pH 5.1）で降水時間は26日午前 3 時から拉日の午前 9 時迄の 18 時間で，鉢植植物に降つた量は $20 \mathrm{~mm}$ であつた。その結果柿では 少數の落葉があり又葉には黑斑が現はれた。䆚苶ではボルドー合劑撒布による 特有の害徴たる小白斑が現れた。

6 月 15--16 日に 6-6 ボルドーを撒布した葆麥に人工雨を降らせた。雨水 は 5 月 31 日に降つた雨 ( $\mathrm{pH} 5.2)$ 学使用し, 同時に比較のため蒸溜水 ( $\mathrm{pH}$ H.6) の雨も降らせた。降水時間は 24 時間で降水量はそれぞれ $11.5 \mathrm{~mm}$ と $12 \mathrm{~mm}$ で ある。其結果蕎麥には兩者基に小白斑が現はれたが，雨水を降らせた方が蒸溜 水の場合よりも被害の程度は秒々著しかつた。

6 月 19 -20 日に再び 6 - 1.5 ボルドーを拤布した薏麥に雨水之蒸溜水を降 らせた。雨水は前と同じものを使用し，降水時間は14 時間とした。降水量は 雨水 $15 \mathrm{~mm}$, 蒸溜水 $18 \mathrm{~mm}$ である。其結果兩者基沙害が現はれたが，雨水 の方がその害がや〉著しかつた。

\section{IV 考察}

實驗 (1)の結果によればボルドー合劑つ種類によつて藥害の程度に差がある けれど女室外區には常に降雨の後に藥害が現はれ，此に反してガラス室內に哭 いそものは何等藥害が現はれなかつた。ガラス室內は室外よりも盜度が高〉乾 燥してわるが雨天の日には天空や側空が開放してあるのであるから其差はあま り大きんもの之は云へない。雨天時に起る日照不足や低溫多濕の狀態はガラス 室內でも起るのであつて此等の綜合的李氣象狀態の影響は室內區といへども受 けてみるのであるが藥害は起らない。それではガラス室內で植物體がボルドー 合劑洋する抵抗力が增したり，藥劑つ性質が變つて藥害が起らなくなるのか と云ふと，長い閒ガラス室に置いたものを室外に取出した場合に藥害が起るの であるか:ら此の樣古考へ方は正しくない事が分る。もつと撒布後長く室內に 置いたものを取出した場合に後になつて生ずる藥害の程度は抄布後間もなく藥 
害の出る室外區に比べて輕いのであるからその樣な傾向はないとは云へない が，佾藥害を全然生ぜしめない程の變化を與へるものではないのである。室外 區之室內區との差は前者では雨が降るのに後者ではガラス屋根があるために雨 が降らない事になるのであるから，藥害の有無を降水と結びつけて考察する事 は不合理でないと考へる。

實驗 (2)の結果によれば柿の葉にボルドー合劑を表裹兩面或は表面のみ塗布 したものに藥害が現はれ，裹面のみに叙布したものでは藥害が現はれない。表 面に狳布したものも葉を裹返して置けば藥害が現はれないのであるから，藥劑 を塗布された面が雨に濡れる事によつて葉に藥害を生するものと思はれる。

實驗 (3)ではボルドー合劑撒布による藥害を人篇的に惹起せしめやうとした

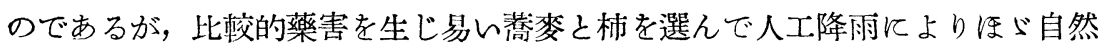
の場合と同じ徽候の藥害を惹起す事が出來た。只:此成績は材料が限られてる るので更にもつと多くの作物汇就て試みなければ確言は出來ないのであるが少 くとも此實驗に供試された作物に就ては自然の場合のボルドー合劑てよる薬害 は降雨によつて葉が濡れる事によつて惹起されるといふ事の一つの論據になり 得ると思ふ。

以上を要約すると

1）ボルドー合劑撒布による藥害は降雨の後に現はれる。

2）ボルドー合劑撒布による藥害が室外では現はれる時にもガラス室內に置 した作物には現はれない。

3）ボルドー合劑を葉に叙布した場合塗布された面が上向の場合にのみ藥害 が現はれる。

4）人工降雨によつてボルドー合劑撒布による藥害を惹起す事が出來る。

以上の 4 項目に基づレてボルドー合劑による藥害は藥劑を撒布されを面が降 雨飞上つて濡れる事によつて惹起され得ると云ふ事が出來ると思ふ。只: 此處 飞斷はつて置かねばならぬのは本實驗では降雨によつて濡れなければ藥害は起 らないといふ逆を證明してわるのではないのであつて，倘降雨以外の藥害を惹 起す可能性のあるもの一例へば露等一飞就ては更に檢討をする必要があるもの と思はれる。 
ボルドー合劑撒布による藥害がガラス室內で起らない事は實用的方面から見 れば，ガラス室內で栽培される作物に撒布するボルドーには藥害を恐れて活染 の甚しん過石灰ボルドーを用ひなくても少石灰ボルドーで間に合ひ，又例へ普 通には藥害に弱い作物でもガラス室栽培の場合には安全にボルドー合劑を撒布 し得る事を示すものである。

ボルドー合劑撒布の作物の生理作用に及度す影響は從來にも相當多く研究さ れてるるが，同化作用，蒸散作用等侍する影響の測定は多くはガラス室內で 行なはれてるる樣であつて，其の樣な場合には作物は後述する如く藥劑の機械 的影響乃至ボルドー合劑のアルカリ性の直接影響を受けてなるに過ざないので あるから自然の降雨に遇つた後の生理作用の變化を知るには充分でない。此の 事はボルドー合劑の生理作用に及惊す影響を研究する上に一考を要する點では あるまんか。

ボルドー合齊利が作物に及度す害作用の機構は甚ざ複雜なものであつて過去本 世紀の間多數の學者によつて多くの研究が行はれて來たが未だ充分明らかにな つてみるとは云ひ得ない樣である。

ポルドー合劑を撒布した場合先づ作物に與へる影響として考へられるのは植 物體の表面を靑白色の藥劑が蔽ふてみるのであるから，植物體に達する輻射が 減するであらうと云ふ事であつて占くより SCHANDER 氐等は其重要性を述へ てるるし，最近其影響を可視光線に就て實测したものもあり，又葉の溫度も其 撒布のものより撒布したものが幾分低ん事も测定されてみる。此等の變化は植 物體の種々な機能に影響を與へ間接に害作用を與へる場合があるに相違ないの であるが然し藥劑が若し表面に附着して被覆作用をしてるるに止まる場合に其 影響のみによつて葉に死斑を生じたり落葉したりする事は常識上考へられない 事であつて，又實際此の被覆作用の最も少ないと思はれる少石灰ボルドーに藥 害が多く過石灰ボルドーに藥害が少ない事からも此のボルドー合劑の機械的影 響 (mechanical effects) は所謂藥害の發生機構とは別個のものと考へる事が出 來ると思子×。

ボルドー合劑撒布による藥害は他の銅を含む殺菌劑の撒布による藥害と同じ く葉や枝に小黑點や時に小白斑の現はれる特異なものであるから藥劑の化學的 
組成殊に其錩成分之不可分の關係がある樣に思はれる。ボルドー合劑は硫酸銅 液と不灰水之を泥合じて調製するが銅は不溶性となつてみて溶液中に銅イオン を檢出する事は出來ない。而も銅イオンは撒布された植物體上の藥齊から㝘易 に檢出されない事から銅イオン以外による害作用の種々な機構が考へられてね たのであるが，最近銅イオンに對する非常に銃敏な呈色区應が見出されて從來 不溶性之思はれてみたボルドー合劑の銅も微量ではあるが溶解する事が知ら れ，一方植物の銅イオンによる被害は非常に低い濃度で夕起り得る事が知られ

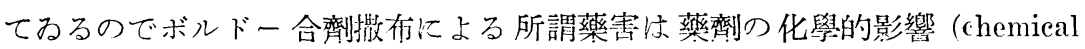
effects）によつて起ると推定し得る可能性が非常に多くなつて來た。

實驗 (1)に於てボルドー合劑の組成分たる硫酸銅と不扊との配合比率と藥害 との關係を見ると何れも不灰の多い力が藥害の現はれ方が进いか或は現はれて も被害の程度は輕微であつた。以上の實驗では 6--18 ボルドーでも份慢微では あるが薬害が現はれ管全に防止する迄に至つてみないが從來から夕よく知られ てみる如く石灰圭多く加へる事によつて藥害を抑制する事がよく認められるの である。们文獻によると石灰の多いボルドー程藥害を惹起し易い場合若二三報 步されてみるが此の嵄な例は特に嫰葉に多い様であつで, 石灰の害を重視する 必要のある事もあるらしく，本論文では敢てるれないが埸合によつてはボルド 一合劑做有による藥害を銅要素之石灰要素之の二つに分けて考慮する必要があ るか名知れない。

植物の組織が銅劑によつて害を受けるにはボルドー合劑中の銅が何等かの方 法で溶解しなければならないが，以前から植物自體上り銅を可溶性とする物澌 を分泌するとか，雨水の溶解性によるとか云はれてるる。籍者は此の點に就て 實驗を行なつてみないので何れが正しんのか明らかにしてみないが，只既に述 べた如く隆雨が藥害の有無を汰定する重要な一雳素である所から雨が此の溶解 作用と密接に關聯してみるらしく思はれる。蒸溜水と丽水とを比較すると雨水 を降らせた方がや〉藥害が著しいから雨水に何か:特別な溶解作用がある樣にも

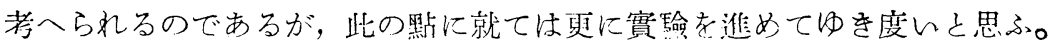

若しボルドー合恋中の銅が雨にとけて組織內に浸入する事とよつて藥害が起 るといふ考へが正しいとすれば實驗(2)から銅イオンは葉の表面の表皮䓇を通 


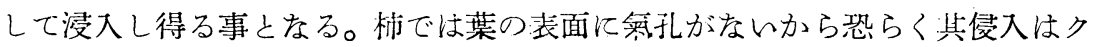
チクラ曆を通して行はれるに相違ない。從つて葉の表面からの侵入を防ぐ役割

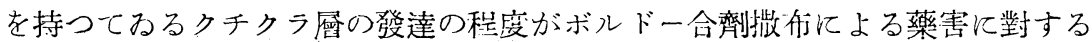
作物の抵抗性の一要素となり得る場合も考へられるのである。實際藥害索被り 易い杮や桃はクチクラの發達が極めて少なく梨や柑榙類は比較的厚いクチクラ 層を持つてみる事は此の㸃と考入合せると何等かの因果關係のある事を示す樣 に思はれる。

\section{$\mathrm{V}$ 摘 要}

1. 梨，柿，桃，䔕萄，荣豆，大豆，小豆等に 4 头圪の少石庅，等量及び過

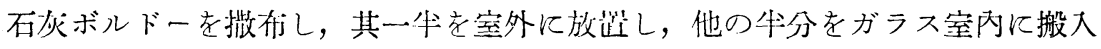
した。室外區に於ては降雨の後に藥害が現はれ，石灰の加用量の少ないもの程 藥害の現はれるるが早くH藥害の程度が著しかつた。ガラス室內に㭡いたもの は室外區に藥害の現はれた時に为何等基常はなかつた。しかし後になつて室外 に出すとやはり藥害を生じた。

2. 㭪の某の表窔网面或は表面のみに 4 斗烒等量ボルドーを撒优したものに 藥害が現はれたが望面のみに叙布したものには藥害が現はれなかつた。表面の

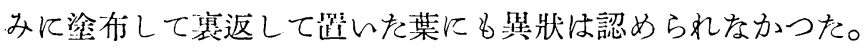

3. 人工降雨によつてボルドー合劑を撒布した杮及荋麥にボルドー合劑撒布 によると同じ藥害を生ぜしめる事が出來た。

4. 以上の結果から見るとボルドー合劑撒布による藥害は撒们された葉面が 雨水に满れる事によつて惹起されるものの樣である。

\section{VI 引用文獻}

(1) Bain, S. M.: The action of copper on leaves. A physiological investigation. Tenn. Agr. Exp. Sta. Bull. 15(2): 19-108, 1902 (Cited by Hedrick)

(2) Hedrick, U. P.: Bordeaux injury. N. Y. Agr. Exp. Sta. Bull. 287, 1907

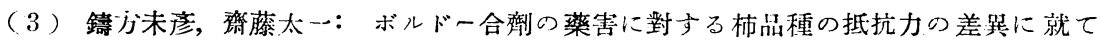
壁及園，4(12): 1422-1427，1929

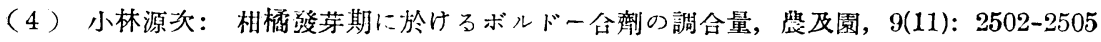
1934.

(5) Kroemer, K. und Schanderl, H.: Quantitative Untersuchungen iiber die 
Strahrungsdurchlassigkeit von Spritzbeiägen der gebrauchlichsten Schädlingskämpfungsmittel des Weinbaues. Gartenbauwiss. 8:672-684, 1934

(6) Schander, R.: Über die physiologische Wirkung der Kupfervitrolkalkbriihe. Landw. Jahrb. 33: 517-584, 1904

(7) Tilford, P. E. and MaY, C.: The effect of Bordeaux mixture on the internal temperature of potato leaflets. Phytopathology 19: 943-949, 1929

(8) Wilcoxon, F. and McCallan, S. E. A.: The weathering of Bordeaux mixture. Contrib. Boyce Thompson Inst. 9 (3): 149-159, 1938

\section{BORDEAUX INJURY AS INDUCED BY RAIN FALL \\ (Preliminary Report) \\ BY}

\section{T. Sugiyama}

\section{SUMMARY}

Potted plants of several sorts, such as persimmons, peacnes, Japanese pears, American grapes, beans, soy-beans, and Azuki-beans, were sprayed with Bordeaux mixtures of 6-1.5-100, 6-6-100, or 6-18-100, After spraying, a half of each treat ment was brought into glass house and the other half was left on in the field. After rain fall Bordeaux injury appeared on the leaves of sprayed plants left in the field, but no injury occured on the plants under glass so far as they stay there. After they had taken out in the field, Bordeaux injury appeared similarlly on them. The injury was severest on the plants sprayed with 6-1.5-100 Bordeaux and slightest on the plants sprayed with 6-18-100 Bordeaux. Some plants sprayed with hydrated lime only were free from injury.

Persimmon leaves were painted with 6-6-100 Bordeaux. The injury was induced on the leaves whose both surfaces or upper surface only were painted. No injury was induced on the leaves whose lower surface only was painted. The leaves reversed after being painted the upper surfaces only were also free from the injury.

As the results of the above experiments seemes to indicate that Bordeaux injury is induced after the sprayed surfaces were wetted by the rain water, the sprayed surfaces of persimmons and buckwheat were wetted artificially with reserved rain water, and after this treatmente for 14-24 hours, typical Bordeaux injury was observed on the wetted surfaces of the sprayed leaves.

These facts are favourable to the assumption that the rain fall induces Bordeaux injury on the sprayed leaves of plants.

It seems that the rain water is necessary to solubilize the copper in the Bordeaux mixture and solubilizing action of the rain water is a little stronger than that of the distilled water, as the injury on the plants wetted with the former is severer than that on the plants wetted with the latter. 